\title{
FUTURE SKILLS IN THE ICT INDUSTRY: QUALITATIVE AND QUANTITATIVE EXAMINATION
}

\author{
Sami Leppimäki and Tarja Meristö \\ Institute for Advanced Management Systems Research (IAMSR), Abo Akademi University, \\ Finland
}

Abstract: The operational environment of the Information and Communication Technology (ICT) industry is in continuous change due to factors like rapid technological development, uncertain economic development and unpredictable consumer behaviour. Consequently, also the skills needed in the ICT industry are changing. Therefore, the quantitative and qualitative demand of ICT professionals in the future is difficult to forecast. However, anticipation and forecasting of the future ICT skills is very important. Issues related to the ICT skills are crucial for the positive development of the ICT industry as it is an extremely information and knowledge intensive industry. In this paper some of the change factors affecting the ICT industry are presented. In addition, quality and quantity of ICT professionals needed in the future is examined based on ICT company surveys and expert interviews. The future of the Finnish ICT industry is also outlined by using scenarios.

\section{INTRODUCTION}

The aim of this paper is to examine what kind of skills the ICT companies need in the future. The examination is based on the ICT company surveys and interviews. The scenario approach is used to examine the alternative future developments of the ICT industry during the next 5-10 years.

This paper is based on recent research, in which the authors of this paper participated. Research projects like the Muunto project (2001, funded by 
Ministry of Education), the TIDE project (2000-2002, funded by European Social Fund and coordinated by Technology Industries Finland), EU ICT Foresight project (2001, funded by Technology Industries Finland), ICT Careers project (2003-2004, coordinated by Technology Industries Finland) form the basis for this examination.

In this paper, we will first present general background information of the ICT industry and main change factors affecting it in the future. Then we examine the results of the ICT company surveys and interviews conducted during the years 2001-2004. Finally we present the scenarios used to map the future of the ICT industry.

\section{THE DEVELOPMENT OF THE FINNISH ICT INDUSTRY}

The Finnish ICT industry has developed very positively over the past decade. The ICT industry is defined here according the OECD's definition in which the ICT industry consist of ICT manufacturing, - services, digital media and telecommunications (OECD 2000; OECD 2002). The number of personnel in the Finnish ICT industry has grown from 100170 in year 1990 to 154000 in year 2002. The economic recession in the early 1990 s did not affect the ICT industry as severely as it did the economy as a whole (Paija, 2001).

Table 1. Turnover and personnel of the Finnish ICT industry in year 2002. (Statistics Finland 2004)

\begin{tabular}{|l|c|c|}
\hline & $\begin{array}{c}\text { Turnover } \\
\text { (billion } € \text { ) }\end{array}$ & Personnel \\
\hline ICT manufacturing & 26.2 & 44300 \\
ICT services (excluding telecommunication) & 9.4 & 47800 \\
Telecommunications & 6.3 & 19800 \\
Content production* & 6.15 & 41800 \\
Total ICT sector & 48.1 & 154000 \\
\hline The adaptors which use ICT include companies in the service and \\
production sectors, public sector organizations, consumers, various \\
electronic and mobile businesses etc.
\end{tabular}

* figures include also so-called traditional content production

The Finnish ICT industry is characterized by the very important role of manufacturing. Its share of turnover exceeds its share of employment. The 
value added of the whole ICT industry has grown significantly, again especially in manufacturing. (Nordic Council of Ministers 2002.)

Figure 1. Value added in Finnish ICT industry in years 1990-2000

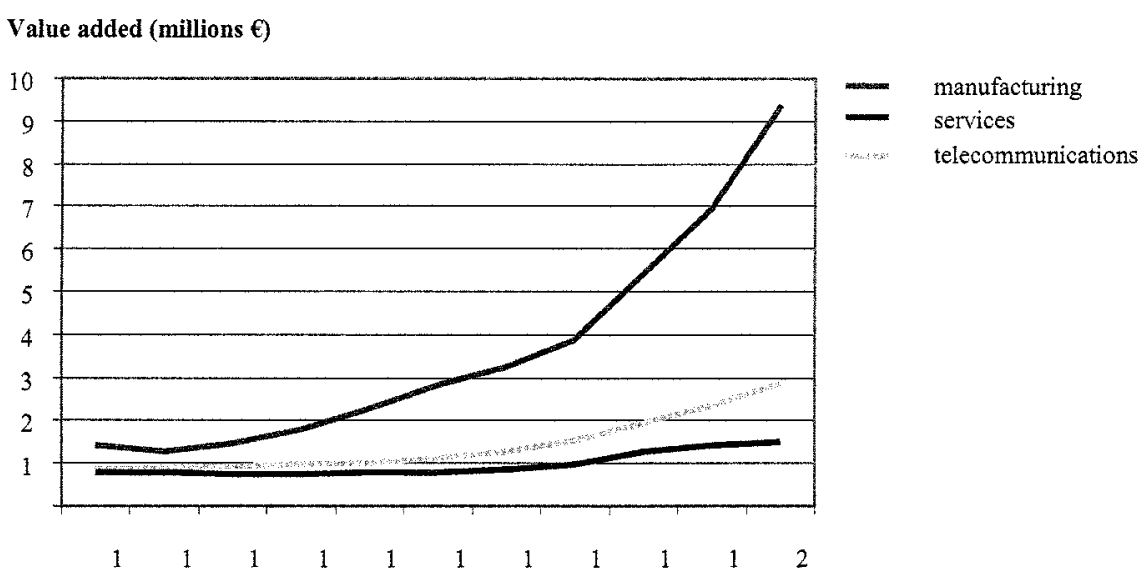

Source: data acquired from Statistics Finland in 3/2002.

\section{FUTURE CHANGE FACTORS AND TRENDS IN FINNISH ICT INDUSTRY}

Based on executive and expert interviews of the ICT companies (Manninen and Meristö 2004; Meristö, Leppimäki and Tammi 2002) the main future change factors and trends in the ICT industry are:

- Convergence of technologies, which among the interviewed was considered to be the most important technological change factor.

- Convergence of the sub-branches of the ICT industry. The convergence is taking place partly as a result of the technological convergence and partly as a normal evolution of the industry.

- Outsourcing of non-core business functions: By outsourcing their less important functions the ICT companies seek cost savings, effectiveness and flexibility. Outsourcing also allows companies to concentrate on their core business. Outsourcing is basically a strategic choice made by the companies. 
- Importance of software is increasing.

- E-commerce and mobility are seen as new possibilities.

- Public investments as a driver for growth of demand: The public administrations in many countries are planning to provide more and more of their services via the Internet and through other communication systems. Therefore, they are building infrastructure and systems for this purpose.

- Specialization into narrower markets and product segments, which is true especially in the small and medium sized companies.

- The increasing importance of ICT in non-ICT products - ICT everywhere.

- Service and customer orientation, which could generate a need for new skill profiles in the ICT industry.

- Strong R\&D investments and quest for new innovations.

- Increase in networking and cooperation.

- Focus on cost efficiency and overall efficiency

- Other factors like the relationship between the ICT sector and other sectors of the economy, the increased weight of the consumer markets (B-to-C) etc.

\section{SKILLS - QUALITATIVE AND QUANTITATIVE EXAMINATION}

In the TIDE-project (2000-2002) the qualitative and quantitative demand of ICT professionals in Finland was explored with an ICT company surveys. The survey questionnaire was sent to 450 ICT companies of which 114 companies replied. The aim of the survey was to examine what kind of skills the companies need in the future. No specific job titles, like 'system specialist' or 'programmer', were used. Instead, the survey focused on the more general characteristics of the employees. The steering group of the TIDE-project selected this approach, because the job titles were often considered to be misleading. It was argued, that in the labor markets the same job titles are used to describe many jobs, which in fact have very different duties and requirements.

Based on the survey's results, the new skills required by the ICT companies, additionally to the certain educational degree, are often qualities of personal nature. Factors like attitudes, world-view, personal communication skills, co-operation skills and project management skills are more important than before when companies are recruiting new staff. Also willingness and ability to learn new things and commitment to goals are 
important. Skills, which were considered to be less important or less desirable, are for example production-line type of skills, multiple degrees and competitiveness. (Meristö, Leppimäki and Tammi 2002.) No significant differences in the desired skills were found between different sub-branches or different sized companies.

Besides new skills, the ICT professionals of the future also have to possess new skill combinations. For example ICT skills combined with business knowledge is one of the desired combinations. Especially in the Finnish digital media companies the lack of business knowledge was considered to be a major problem. Based on the comments of the survey respondents and interviews, it could be argued that the educational structure of the workforce in the ICT industry is changing and the level of education rising. The new needs of the ICT companies are reflecting the changes taking place inside the ICT industry, but also in the relationship between the ICT and other sectors of the economy and society. The ICT and its integration into strategic thinking and business models has become a necessity in sectors like banking, manufacturing and retail. The other sectors would also like their ICT professionals to have some basic knowledge and skills related to their specific industry and business. In other words, ICT has entered into the core of these businesses (Meristö, Leppimäki and Tammi 2002). Also the core of the ICT industry itself is changing since one of the main development trends listed earlier in this paper is the increased use of outsourcing.

Besides information concerning the skills needed in the ICT industry, the survey also produced estimates concerning the number of employees in the ICT industry in the future. The ICT service companies estimated the highest growth in the number of employees. ICT manufacturing companies estimated more modest growth and telecommunication companies estimated that their number of employees will stay approximately unchanged (see Figure 2 on the next page). 
Figure 2. The employment of the Finnish ICT industry, forecast from year 2000 to 2010. (Forecast based on growth estimates indicated by respondents in the ICT company survey. These estimates were then extrapolated to cover the ICT industry as a whole. Starting values were from Statistics Finland 2001)

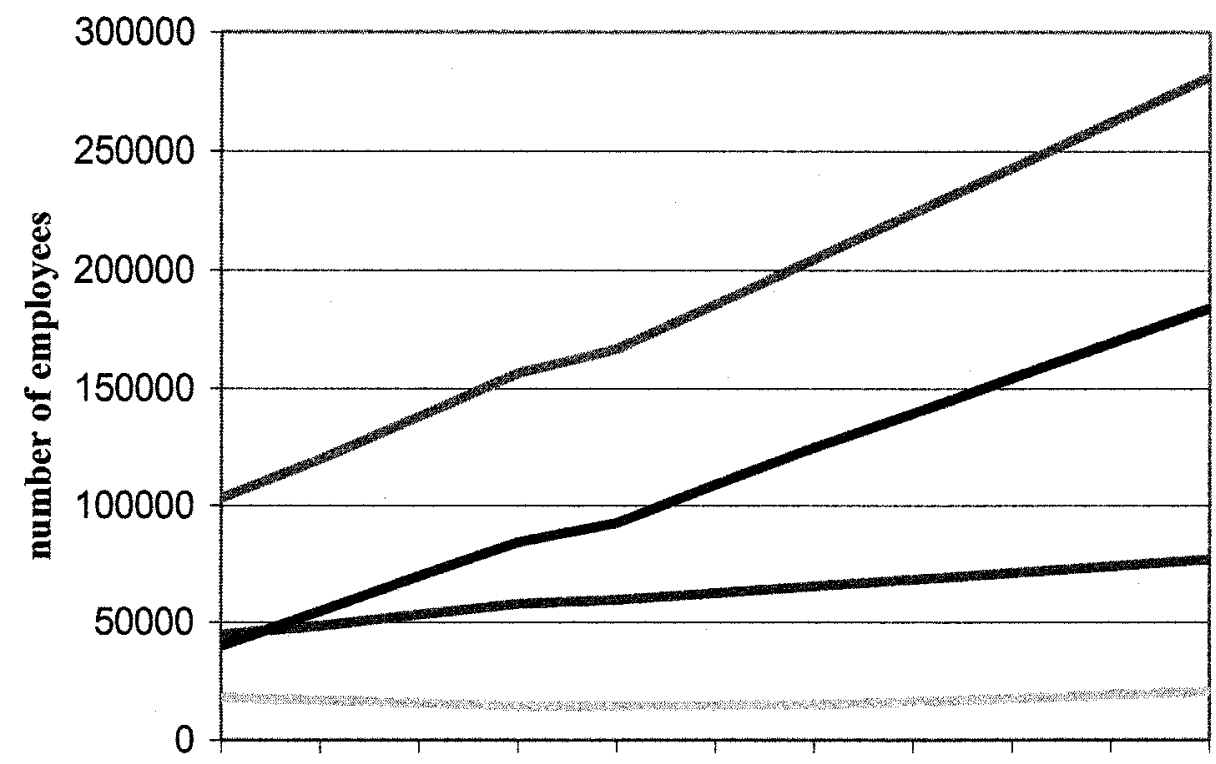

20002001200220032004200520062007200820092010 year

manufacturing telecommunications - services total

\section{SCENARIOS}

In the TIDE project the future developments of the ICT industry and the Information Society was explored by constructing alternative future scenarios. The scenarios were constructed from the view point of the ICT industry. The time span of the scenarios was till year 2010. The scenarios were based on selected driving forces i.e. powerful change factors capable of changing the course of development. The driving forces were derived from the background research, survey data and expert interviews. Thus, the scenarios are not derived straight from the change factors listed earlier. Although, some change factors are clearly the main driving forces behind certain scenarios. For example, 'strong R\&D investments and quest for new 
innovations' is the main driving force behind scenario II. In addition some scenarios are constructed to challenge the basic beliefs of the ICT-industry or to illustrate threats which could jeopardize the positive development of the ICT industry. Many of the change factors listed earlier indicated that the future of the ICT industry would be distinctively technology and market led. Therefore also the strengthened role of society was deliberately illustrated in one scenario. The resulting scenarios are logical stories illustrating the developments that these driving forces could set off.

The four scenarios constructed are:

I Sustainable development and Information Society. In this society led scenario the positive development of the Information Society is combined with the principles of the sustainable development. Although the scenario is strongly promoted by the political and societal elite, it also has the support of the general public. In this scenario the Finnish model of Information Society (Castells and Himanen 2001) is a success story.

II Innovation Boom of the ICT sector. This technology led scenario could be characterized to be a continuation of the past development of the ICT industry. In this "business as usual" scenario the development of the industry is technology oriented. The society supports the development, but does not steer it. This is clearly a technology push type of scenario, where the needs of the people and consumer are not always sufficiently taken into account.

III U.S. Recession. This market driven scenario describes a development were the global economy plunges into a deep recession and the outlook of the ICT industry is very negative due to the diminishing demand of ICT products and services. Although the world economy eventually recovers from the recession, the ICT industry remains permanently on a more negative development path.

IV Security Risks Materialize. This is a threat-scenario, which is included and shared by the scenarios I, II and III. The scenario illustrates a development where the risks associated to the rapid development and implementation of the ICT come true. The possible risks include for example computerized crime, insecurity of the payment transactions in e \& mcommerce, privacy issues, sabotage, virtual terrorism and infrastructure vulnerabilities.

The views of the ICT companies presented in the survey answers were examined once more by cluster analysis. The companies were clustered in 
terms of how they saw their own and the whole ICT industry's future prospects, markets, threats, effects of the technological development, opportunities etc. As a result of this analysis the companies were divided into four groups according to what scenario they believed in. From the basis of cluster analysis the fourth scenario, i.e. Security Risks Materialize, did not appear to be feasible enough to be treated as an independent scenario. Therefore, it was considered as a threat scenario shared by the other three scenarios. Finally the companies were divided into three groups according to what scenario (I, II or III) they seem to believe.

Figure 4. What scenario does the Finnish ICT industry believe in? (\% of the respondents) (scenario IV omitted) (Meristö, Leppimäki and Tammi 2002)

Innovation Boom of the ICT sector
$27 \%$
$\begin{aligned} & \text { Sustainable } \\ & \text { Development and } \\ & \text { Information } \\ & \text { Society } \\ & 39 \% \\ & \mathrm{CT} \text { industry }= \\ & \mathrm{CT} \text { manufacturing, ICT services, } \\ & \mathrm{e}=106\end{aligned}$ U.S. Recession $34 \%$

Figure 4 shows that the Finnish ICT industry sees the sustainable development combined to Information Society development as a very feasible future scenario. It could be said, that the ICT industry strongly is supporting this kind of development. At the same time, there is also a strong belief in technology driven development. In addition, one third of the companies see global recession as the most possible future scenario. 


\section{CONCLUSIONS}

The current trends of the ICT industry suggest that the strategic choice of the industry has been to move closer to the customers and into products with higher value added. In addition, the companies have transformed themselves from pure manufacturers to service providers, consultants and eventually to solution providers. (Manninen and Meristö 2004) These strategic choices have their influence on the skills of the employees needed in the ICT industry.

Over time the ICT has entered into the core of many sectors of the economy. More and more ICT is embedded into various every day products not forgetting the production and distribution of these products. Consequently, also the ICT skills and skill profiles are in continuous change. It is for example becoming almost obligatory for ICT professionals to have some business or marketing skills. Also the ICT industry itself will need new employees with new skills in the future. The qualitative skills gap is among the Finnish ICT companies often considered to be a more serious problem than the quantitative skill shortage. The educational system has been able to meet the quantitative demands, but not the qualitative ones. (Meristö, Leppimäki and Tammi 2002.) All things considered, the rapid development of the ICT creates new challenges to the educational system and the curricula of the educational institutes. Therefore, it is very important to update the curricula.

The Finnish government has actively pursuit development which would lead into a real Information Society. As the results of this research show, also the ICT industry sees the Information Society development as a desirable future scenario.

\section{REFERENCES}

Castells, M. and Himanen, P. 2001, Suomen tietoyhteiskuntamalli, SITRA and WSOY, ISBN

Koski, H. et al. 2001. Uuden talouden loppu? ETLA B 184. The Research Institute of Finnish Economy (in Finnish, English abstract included)

Manninen A, Meristö, T. 2004. Tulevaisuuden ICT-osaaminen - Yritysten ja yksilöiden strateginen haaste. IAMSR, Åbo Akademi, April 2004. (in Finnish, English abstract included)

Meristö, T, Leppimäki, S. and Tammi, M. (2002), ICT Osaaminen 2010, Tietoteollisuuden ja digitaalisen viestinnän osaamisen ennakointi. Åbo Akademi, ISBN 952-12-1000-1 (in Finnish, English abstract included)

OECD 2000. Information Technology Outlook. OECD. 
OECD 2002, Measuring the Information Economy, on line at http://www.oecd.org/document $/ 5 / 0,2340$,en_2649_37441_2765701_1_1_1_37441,00.html accessed $18^{\text {th }}$ of Feb. 2005

Paija, L. (ed.) 2001. Finnish ICT Cluster in the Digital Economy. ETLA B 176. The Research Institute of Finnish Economy

Nordic Council of Ministers 2002. Nordic Information Society Statistics 2002. Statistics Denmark, Statistics Finland, Statistics Iceland, Statistics Norway, Statistics Sweden ISBN 952-467-109-3, Yliopistopaino, Helsinki 2002.

Statistics Finland 2001, Tiedolla tietoyhteiskuntaan III. (in Finnish)

Statistics Finland 2004, Informaatiosektori toimialoittain 2002. (in Finnish) 